\title{
The chemical composition of two seaweed flies (Coelopa frigida and Coelopa pilipes) reared in the laboratory
}

\author{
I. Biancarosa ${ }^{1,2}$, N.S. Liland ${ }^{1 *}$, N. Day ${ }^{3}$, I. Belghit ${ }^{1}$, H. Amlund ${ }^{1}$, E.-J. Lock ${ }^{1}$ and A.S. Gilburn ${ }^{3}$ \\ ${ }^{1}$ Institute of Marine Research, Nordnesgaten 50, 5005 Bergen, Norway; ${ }^{2}$ University of Bergen, Department of Biology, \\ Thormøhlensgt. 53 A/B, P.O. Box 7803, 5020 Bergen, Norway; ${ }^{3}$ University of Stirling, Biological and Environmental Sciences, \\ Stirling FK9 4LA, Stirling, United Kingdom; nli@nifes.no
}

Received: 18 January 2018 / Accepted: 7 April 2018

(c) 2018 Wageningen Academic Publishers

OPEN ACCESS CC) (요요 RESEARCH ARTICLE

\begin{abstract}
Two species of seaweed flies, Coelopa frigida and Coelopa pilipes, were reared in the laboratory and their larvae were sampled for composition of amino acids, fatty acids and elements. The larvae were grown on two different species of seaweed, Laminaria digitata and Fucus serratus. The aim was to gain knowledge on the influence of feeding media on the growth and composition of the larvae. F. serratus was more nutrient-dense than L. digitata, being richer in both protein and lipids, and thus led to $\sim 70 \%$ higher larvae growth. The larvae grown on $F$. serratus also had higher lipid and protein content than the larvae grown on L. digitata; F. serratus-grown larvae had $\sim 8-9 \%$ protein and $~ 18 \%$ lipid (total fatty acids) (both values of dry matter), while the larvae grown on L. digitata had only 7.5\% protein and $\sim 13 \%$ lipids. All seaweed flies had a similar and balanced amino acid composition, suitable for animal and human nutrition. The fatty acid composition was not highly affected by either insect species or feeding media, with all groups containing high concentrations of the monounsaturated fatty acid, palmitoleic acid (16:1n-7). The larvae also contained some fatty acids characteristic of marine environments, like eicosapentaenoic acid (20:5n-3), likely originating from the seaweed. Both species of seaweed fly larvae accumulated $\mathrm{As}, \mathrm{Cd}$, and $\mathrm{Pb}$, but not $\mathrm{Hg}$. The elevated levels of As and Cd in the larvae (highest measured concentrations 18.4 and $11.6 \mathrm{mg} / \mathrm{kg}$, respectively, based on $12 \%$ moisture content) could potentially limit the use of seaweed fly larvae as a feed ingredient.
\end{abstract}

Keywords: insects, fatty acid, amino acid, brown algae, heavy metals

\section{Introduction}

Insects are becoming increasingly important for use in human and animal food chains and may develop as important as sources of nutrients (Henry et al., 2015). Insect larvae can be naturally rich in protein and micronutrients and have favourable compositions of essential amino acids (Barroso et al., 2014; Makkar et al., 2014). Most studies on insects have been performed on species that feed on matter of terrestrial origin, such as (Tenebrio molitor), superworm (Zophobas morio), silkworm (Bombyx mori) and black soldier fly (Hermetia illucens) (Henry et al., 2015). Insects feeding on matter of marine origin have been found to be richer in omega-3 polyunsaturated fatty acids (PUFA) than insects growing on terrestrial media (Fontaneto et al., 2011; Liland et al., 2017; St-Hilaire et al., 2007). There are small numbers of terrestrial insects that naturally feed upon decomposing matter of marine origin. Amongst these insects are the seaweed flies (Diptera: Coelopidae). This is a small family of coastal flies that are entirely dependent upon beached wrack for the development of their larvae. Two species, Coelopa frigida and Coelopa pilipes, are common in Northern Europe (Edward et al., 2007). Both species inhabit wrack beds primarily composed of brown algae (Phaeophyta), especially the genera Laminaria and Fucus (Dobson, 1974). The deposition of fresh seaweeds upon beaches, following storm events and spring high tides, attracts adult flies and stimulates mating and oviposition (Dunn and Crean, 2002). The larvae of both species feed on the decaying seaweeds and the bacteria found on the seaweed surface (Cullen et al., 1987; Dobson, 1974). The larvae are often washed out of the wrack by storm events 
and spring high tides where they become natural prey to fish such as bass (Dobson, 1974). Both C. frigida and C. pilipes have been successfully cultured in the laboratory (Edward et al., 2007). No data are available on the nutritional or contaminant composition of these fly species. We aim to address this knowledge gap.

In the current study, C. frigida and C. pilipes larvae were reared in laboratory-scale facilities, using $L$. digitata or $F$. serratus as sole feeding substrates. The main aim of the study was to investigate the chemical composition of the insect larvae, and to gain knowledge on the composition of insects that naturally feed on matter of marine origin.

\section{Materials and methods}

\section{Laboratory culture}

Two species of brown algae: Laminaria digitata (Huds.) and Fucus serratus (L.) were collected from wrack bed deposits in Fife, Scotland. Seaweed was collected at two different days at two locations. The reason for several collection days was the need to repeat some of the treatments, while different locations were used as individual locations are inconsistent in their availability of wrack due to the direction of prevailing winds. The collection locations were Kingsbarns (N $\left.56^{\circ} 18.200 \mathrm{~W} 002^{\circ} 38.670\right)$ which faces north east and Cellardyke Harbour (N 56 $13.500 \mathrm{~W} 002^{\circ}$ 41.000) which faces south west. The wrack was sorted on the beach and then frozen at $-20{ }^{\circ} \mathrm{C}$. The seaweed was then defrosted and washed prior to being minced using a buffalo meat mincer to increase the surface area and rate of decomposition of the seaweed. Two species of seaweed flies (C. frigida and C. pilipes) were reared in laboratory-scale facilities at the University of Stirling, Scotland. All culturing was carried out in $10 \mathrm{l}$ food storage boxes (Addis, Bridgend, UK) kept in the same room at constant temperature of $25^{\circ} \mathrm{C}$, $60 \%$ humidity and a 12:12 light-dark cycle. A hole was cut in the lid of each box and covered with paper towels to allow aeration of the cultures while preventing escapes of insects. Two kg of minced seaweed were added to each box. Fifty adult flies with a 50:50 sex ratio were added to each box. These flies came from laboratory populations established from wild collections of both species of coelopids from Kingsbarns. Six replicates boxes were established for each of the four treatments: (1) C. frigida grown on L. digitate; (2) C. frigida grown on F. serratus; (3) C. pilipes grown on L. digitata; and (4) C. pilipes grown on F. serratus.

\section{Sampling}

On day four after establishing the cultures, one sample of approximately $150 \mathrm{~g}$ biomass (larvae + seaweed) was removed from each box using a metal spoon. This sampling point was selected as it was expected that the larvae were at the largest size with the highest lipid and protein content
(N.S. Liland, unpublished data) before pupation. The sample was weighed and the larvae were subsequently collected. The larvae were collected with a spoon, rinsed in water, dried on tissue paper and finally frozen on dry ice. The weight of the collected larvae collected from each sample was registered.

\section{Sample processing}

Frozen samples of the seaweed feeding media and larvae were ground to a powder by using a blender (Knife Mill Frindomix GM 200; Retsch, Haan, Germany). Dry ice was added in the blending process to prevent thawing of samples. Due to poor growth in some crates resulting in small sample size, samples from two crates were pooled (crate $1+2$, crate $3+4$, crate $5+6$ for each group). One sample per seaweed species (a total of two samples) and three samples per insect/seaweed group (a total of twelve samples) were thus analysed. Aliquots of the samples were lyophilized for the content of dry matter by first freezing $24 \mathrm{~h}$ at $-20^{\circ} \mathrm{C}$ in vacuum (0.2-0.01 $\left.\mathrm{mBar}\right)$, then leaving in vacuum at $25{ }^{\circ} \mathrm{C}$ until constant weight.

\section{Chemical analyses}

Analysis of total amino acids (except cysteine and tryptophan) of feeding media and larvae was carried out in technical duplicates by ultra-performance liquid chromatography (UPLC, Acquity UPLsC system; Waters, Milford, MA, USA) coupled with a UV detector (Biancarosa et al. , 2017a). Wet, powdered samples (containing $40 \mathrm{mg}$ of protein) were hydrolysed in $6 \mathrm{M} \mathrm{HCl}$ at $110^{\circ} \mathrm{C}$ for $22 \mathrm{~h}$. Prior to hydrolysis, $3.125 \mathrm{mM}$ Norvaline (Sigma-Aldrich, St. Louis, MO, USA) was added as internal standard, and $0.1 \mathrm{M}$ dithiothreitol (Sigma-Aldrich) as an antioxidant agent to protect methionine from degradation during acid hydrolysis. For a further protective aid, sample tubes were topped up with nitrogen gas. During acid hydrolysis, cysteine and tryptophan are destroyed and are therefore not reported in the results. After hydrolysis, samples were cooled to room temperature and centrifuged in a vacuum centrifuge until complete dryness was reached. After centrifugation, the residue was diluted in deionized water (MilliQ-Plus, Billerica, MA, USA) and filtered through a syringe-driven filter. Prior to the instrumental analysis, a derivatisation agent (AccQ.Tag ${ }^{\mathrm{ma}}$; Waters) was added to each sample. Finally, amino acids were separated by UPLC (column: Aquity UPLC BEH C18 $1.7 \mu \mathrm{M}$, flowrate $0.7 \mathrm{ml}$ / min; Waters) and results integrated by Empower 3 (Waters). Protein content of media and larvae is here presented as sum of anhydrous amino acids (also called true protein), a more accurate estimation of protein than $\mathrm{N}$-content $x$ protein factors (Biancarosa et al., 2017a).

Fatty acid composition was determined for feeding media and larvae and analysed in technical duplicates as 
described by Torstensen et al. (2004). Briefly, lipids were extracted from wet, powdered samples by homogenisation in chloroform:methanol (2:1, v:v) and analysed using gas chromatography coupled with a flame ionisation detector. The following instrumentation was used: Autosystem XL (Perkin Elmer, Waltham, MA, USA) with pre-column Silica $0.53 \mathrm{~mm}$ i.d. (Imperial Eastman Tubing, Baltimore, MD, USA) and a CP-sil- $88^{\text {Tm }}$ column, $50 \mathrm{~m} \times 0.32 \mathrm{~mm}$ i.d. Helium was used as carrier gas at $1.5 \mathrm{ml} / \mathrm{min}$ and hydrogen as a detector gas at $45 \mathrm{ml} / \mathrm{min}$. The peaks were identified with the software Chromeleon version 6.8 (Dionex, Sunnyvale, CA, USA) and individual methyl esters were identified by comparison to known standards and on the basis of published values (Ackman, 1980). Quantification of fatty acids was done by using 19:0 methyl ester as an internal standard.

Element concentrations in freeze-dried, powdered material of feeding media and larvae were analysed by inductively coupled plasma-mass spectrometry (ICPMS) after wet digestion in a microwave oven, based on Julshamn et al. (2001). Briefly, the samples (approximately $0.2 \mathrm{~g}$ of dry sample) were digested in $69 \%$ nitric acid (2 $\mathrm{ml}$; Sigma-Aldrich) and 30\% hydrogen peroxide $(0.5 \mathrm{ml}$; Merck Millipore, Billerica, MA, USA) using a microwave digestion system (UltraWAVE; Milestone, Sorisole, Italy). The solutions were diluted to $25 \mathrm{ml}$ with deionized water (MilliQ plus; Merck Millipore). Element concentrations in the samples were quantified by ICP-MS (iCapQ ICPMS; Thermo Fisher Scientific, Waltham, MA, USA) equipped with an autosampler (FAST SC-4Q DX; Elemental Scientific, Omaha, NE, USA). Data were collected and processed using the Qtegra ICPMS Software (Thermo Fisher Scientific).

\section{Statistical analysis}

All statistical analyses were performed using the statistical environment R (R Development Core Team, 2017). Twoway ANOVA was performed using linear models (variables: insect species and seaweed feeding media). Homogeneity in variance and normal distribution were verified by graphical evaluation using the plot function in $\mathrm{R}$ (residuals vs fitted, normal Q-Q plot, scale-location plot, residuals vs leverage plot) as well as numerically by Levene's test and a ShapiroWilks test. Data not suitable for ANOVA analysis was analysed using Kruskal-Wallis.

\section{Results}

\section{Growth of the larvae}

The larvae that had grown on $F$. serratus had a larger biomass at the end of the four-day growth period compared to the larvae grown on L. digitata $(\sim 70 \%$ higher biomass per crate, Figure 1). Due to loss of data, only four replicate values for growth are reported in the $C$. frigida grown on L. digitata, while there are six for the other groups.

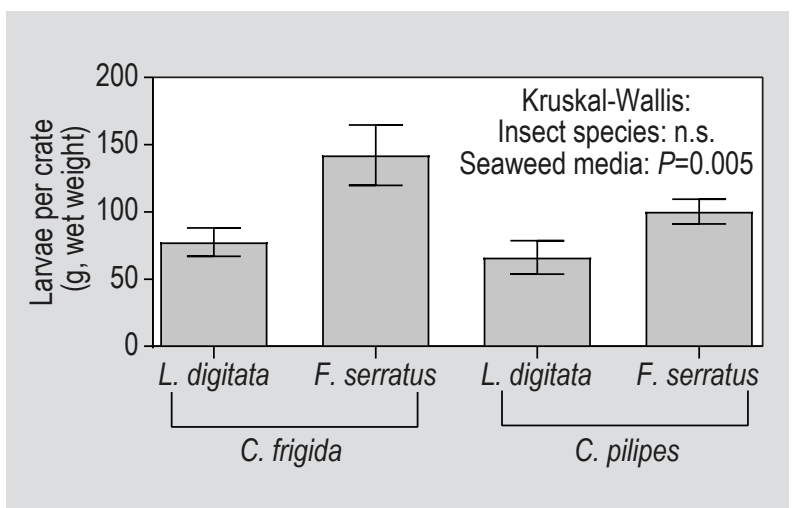

Figure 1. Total mass of seaweed larvae (Coelopa frigida and Coelopa pilipes) after a four-day growth period on either Laminaria digitata or Fucus serratus (g per crate). Data are expressed as mean values of six replicate crates per treatment \pm SEM ( $n=4$ for $C$. frigida on L. digitata).|

\section{Composition of the seaweed feeding media}

F. serratus had lower content of dry matter than L. digitata, but $F$. serratus had higher protein content (on dry weight basis) than L. digitata (Table 1). Both seaweed species were, however, low in several essential amino acids, namely phenylalanine that was below the quantification limit in L. digitata, while histidine and methionine were below the quantification limit in both algae species (Table 2). The lipid concentrations were also higher in F. serratus ( $\sim 9 \%$ lipids on dry weight basis) than in L. digitata, that had less than $1 \%$ lipid (Table 1). Both seaweed species had similar concentrations of saturated, monounsaturated and polyunsaturated fats, but L. digitata had a higher n-3/n-6 ratio than F. serratus (Table 3).

The seaweed feeding media contained similar levels of macrominerals, although the concentration of $\mathrm{Na}$ was lower in L. digitata than in F. serratus (Table 4). There were differences in the concentrations of microminerals, L. digitata contained higher concentrations of $\mathrm{Fe}, \mathrm{Cu}$, and $\mathrm{Zn}$, and lower concentrations of Mn, than F. serratus, while the level of Se was similar in the two species (Table 4). The levels of the heavy metals $\mathrm{Cd}, \mathrm{Hg}$, and $\mathrm{Pb}$ were low, while the levels of As were high in both species (Table 4). The levels of As were twice as high in L. digitata compared to F. serratus.

\section{Composition of the larvae}

The insect larvae grown on $F$. serratus had higher content of dry matter, protein, and total fatty acids than the larvae grown on L. digitata (Table 1). There was a lower concentration of the essential amino acid histidine in C. pilipes than in C. frigida (Table 2). C. pilipes also contained less phenylalanine than C. frigida, while C. frigida contained more lysine, methionine, and valine 
Table 1. Proximate composition of the seaweed media (the brown algae Laminaria digitata and Fucus serratus) and the two species of seaweed fly larvae (Coelopa frigida or Coelopa pilipes) grown on either $L$. digitata or $F$. serratus. Data are expressed as mean values of three replicates \pm standard deviation for insects and the mean of two technical replicates for the seaweed media. ${ }^{1,2}$

\begin{tabular}{|c|c|c|c|c|c|c|c|c|c|}
\hline & \multicolumn{2}{|c|}{ Seaweed media } & \multicolumn{2}{|l|}{ C. frigida } & \multicolumn{2}{|l|}{ C. pilipes } & \multirow[t]{2}{*}{ I } & \multirow[t]{2}{*}{ s } & \multirow[t]{2}{*}{ IXS } \\
\hline & L. digitata & F. serratus & L. digitata & F. serratus & L. digitata & F. serratus & & & \\
\hline Dry weight (\%) & 23.8 & 10.4 & $19.1 \pm 2.0$ & $21.5 \pm 1.4$ & $16.4 \pm 0.8$ & $23.1 \pm 1.0$ & NS & * & NS \\
\hline True protein ( $\mathrm{g} / 100 \mathrm{~g} \mathrm{dm})$ & 1.0 & 2.3 & $7.3 \pm 0.6$ & $7.8 \pm 0.4$ & $7.4 \pm 0.5$ & $8.9 \pm 0.6$ & NS & * & NS \\
\hline Total FA (g/100 g dm) & 0.8 & 8.8 & $12.1 \pm 3.4$ & $19.7 \pm 3.7$ & $14.2 \pm 5.0$ & $16.8 \pm 0.2$ & NS & * & NS \\
\hline
\end{tabular}

Table 2. Amino acid composition (\% of total amino acids) of the seaweed media (the brown algae Laminaria digitata and Fucus serratus) and the two species of seaweed fly larvae (Coelopa frigida or Coelopa pilipes) grown on either $L$. digitata or $F$. serratus. Data are expressed as mean values of three replicates \pm standard deviation for insects and the mean of two technical replicates for the seaweed media. ${ }^{1,2}$

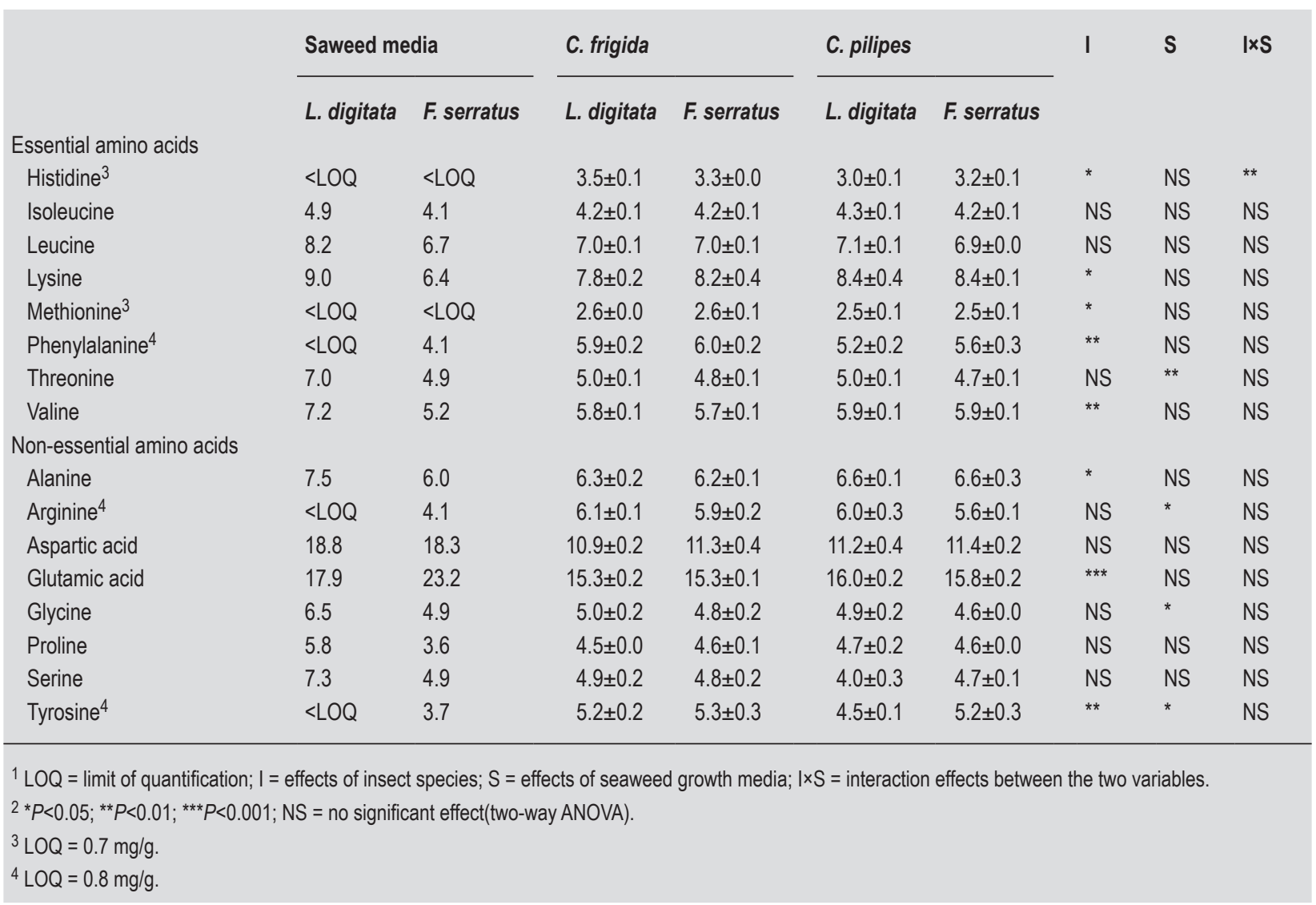

than C. pilipes. The larval concentrations of saturated and monounsaturated fats were similar between both species and feeding media (Table 3). The same was true for the polyunsaturated fatty acids, with the exception of $C$. frigida grown on $F$ serratus, which had almost $20 \%$ PUFA (of total fatty acids), compared to the other groups with values $\sim 13 \%$ of total fatty acids. All the larvae samples had high concentrations of the monounsaturated fatty acid palmitoleic acid (16:1n-7, 25-30\% of total fatty acids) and stable concentrations of eicosapentaenoic acid (EPA; $\sim 3.5 \%$ of total fatty acids). 
Table 3. Fatty acid composition (area \%) of two species of seaweed fly larvae (Coelopa frigida or Coelopa pilipes) grown on two species of brown algae (Laminaria digitata or Fucus serratus). Data are expressed as mean values of three replicates \pm standard deviation for insects and the mean of two technical replicates for the seaweed media. ${ }^{1,2}$

\begin{tabular}{|c|c|c|c|c|c|c|c|c|c|}
\hline & \multicolumn{2}{|c|}{ Seaweed media } & \multicolumn{2}{|l|}{ C. frigida } & \multicolumn{2}{|l|}{ C. pilipes } & \multirow[t]{2}{*}{ I } & \multirow[t]{2}{*}{ s } & \multirow[t]{2}{*}{ IXS } \\
\hline & L. digitata & F. serratus & L. digitata & F. serratus & L. digitata & F. serratus & & & \\
\hline $14: 0$ & 4.5 & 8.7 & $6.6 \pm 0.8$ & $6.2 \pm 0.8$ & $4.8 \pm 0.9$ & $4.6 \pm 0.5$ & * & NS & NS \\
\hline $16: 0$ & 19.0 & 14 & $16.8 \pm 1.5$ & $17.7 \pm 0.8$ & $19.2 \pm 1.0$ & $19.1 \pm 0.3$ & * & NS & NS \\
\hline $18: 0$ & 0.9 & 0.5 & $1.5 \pm 0.4$ & $1.6 \pm 0.2$ & $2.1 \pm 1.1$ & $2.3 \pm 0.2$ & NS & NS & NS \\
\hline Total SFA & 25.6 & 24.5 & $27.0 \pm 2.0$ & $26.0 \pm 0.6$ & $27.1 \pm 0.2$ & $26.5 \pm 0.3$ & NS & NS & NS \\
\hline $16: 1 n-7$ & 7.4 & 1.4 & $30.6 \pm 3.8$ & $25.1 \pm 1.9$ & $28.6 \pm 3.4$ & $30.3 \pm 1.0$ & NS & NS & NS \\
\hline $18: 1 n-9$ & 11.3 & 22 & $13.9 \pm 1.7$ & $17.7 \pm 1.5$ & $17.3 \pm 4.1$ & $17.1 \pm 0.5$ & NS & NS & NS \\
\hline $18: 1 n-7$ & 0.6 & 0.3 & $4.6 \pm 1.8$ & $3.3 \pm 1.1$ & $4.3 \pm 0.3$ & $4.4 \pm 0.6$ & NS & NS & NS \\
\hline Total MUFA & 20.5 & 24.5 & $51.4 \pm 6.7$ & $48.4 \pm 1.1$ & $52.4 \pm 5.3$ & $53.3 \pm 0.5$ & NS & NS & NS \\
\hline $18: 2 n-6$ LA & 2.9 & 9.5 & $2.4 \pm 0.7$ & $5.3 \pm 0.9$ & $3.1 \pm 1.7$ & $3.3 \pm 0.8$ & NS & * & NS \\
\hline $18: 3 n-3$ ALA & 5.7 & 5.3 & $1.5 \pm 1.0$ & $2.5 \pm 0.2$ & $1.6 \pm 0.8$ & $1.8 \pm 0.2$ & NS & NS & NS \\
\hline $18: 4 n-3 S A$ & 10.7 & 5.9 & $1.6 \pm 1.2$ & $1.7 \pm 0.1$ & $1.3 \pm 0.5$ & $1.4 \pm 0.1$ & NS & NS & NS \\
\hline $20: 4 n-6$ ARA & 9.3 & 12.7 & $3.8 \pm 1.1$ & $4.4 \pm 0.4$ & $3.1 \pm 0.9$ & $2.7 \pm 0.2$ & * & NS & NS \\
\hline 20:5n-3 EPA & 13.6 & 9.1 & $3.9 \pm 1.9$ & $4.3 \pm 0.4$ & $3.1 \pm 1.0$ & $2.9 \pm 0.3$ & NS & NS & NS \\
\hline $22: 6 n-3$ DHA & $<L O Q$ & $<L O Q$ & $<L O Q$ & $<L O Q$ & $<L O Q$ & $<\mathrm{LOQ}$ & - & - & - \\
\hline Total $n-3$ & 33 & 22 & $6.1 \pm 4.0$ & $8.6 \pm 0.7$ & $6.0 \pm 2.2$ & $6.1 \pm 0.5$ & NS & NS & NS \\
\hline Total n-6 & 13 & 24 & $6.5 \pm 2.1$ & $10.7 \pm 1.4$ & $6.7 \pm 2.6$ & $6.6 \pm 0.9$ & NS & NS & NS \\
\hline$n-3 / n-6$ & 2.5 & 0.9 & $0.9 \pm 0.3$ & $0.8 \pm 0.1$ & $0.9 \pm 0.1$ & $0.9 \pm 0.1$ & NS & NS & NS \\
\hline Total PUFA & 46 & 46 & $12.6 \pm 6.1$ & $19.5 \pm 2.2$ & $13.5 \pm 4.5$ & $12.8 \pm 1.3$ & NS & NS & NS \\
\hline
\end{tabular}

In the fly larvae, the concentrations of the macrominerals $\mathrm{Ca}, \mathrm{Mg}$ and $\mathrm{P}$ were generally higher in C. pilipes than in C. frigida, while the concentrations of microminerals where more affected by which species of seaweed they had been grown on (Table 4). Larvae grown on F. serratus had higher concentrations of Mn than larvae fed L. digitata, reflecting the higher concentration of Mn in F. serratus. Similarly, larvae grown on L. digitata had higher concentrations of Fe than larvae fed F. serratus, reflecting the higher concentration of $\mathrm{Fe}$ in $L$. digitata. The larval concentrations of $\mathrm{Cu}, \mathrm{Zn}$, and Se were only lightly affected by the feeding media. The levels of $\mathrm{Hg}$ and $\mathrm{Pb}$ in larvae were low in all groups, while elevated levels of As and Cd were found. The level of As was higher in larvae grown on L. digitata compared to larvae fed $F$. serratus, reflecting the higher level of As in L. digitata than in F. serratus. Cd accumulated in all groups of fly larvae. Interestingly, the level of $\mathrm{Cd}$ was lower in C. frigida fed L. digitata than in the three other groups of seaweed fly larvae.

\section{Discussion}

Seaweed fly larvae were successfully grown in the lab, although no large quantities of larvae were harvested in the process, and as such, the production of seaweed fly larvae for use in feed or food purposes is still not practically viable. The lower growth of both seaweed fly species on L. digitata is a consequence of a poorer nutrient content of this seaweed species, being lower in both protein and lipids than F. serratus. This was also reflected in the lower nutrient content of the larvae that had eaten L. digitata.

Lipid and especially protein content of the larvae were low compared to larvae of insect species commonly used in commercial production, such as black soldier fly prepupae ( $40 \%$ protein and $40 \%$ fat) or pre-pupae of the common housefly (60\% protein and $20 \%$ fat) (Veldkamp et al., 2012). The concentrations of histidine in the larvae were lower than in other animal sources, like fishmeal, which typically has histidine concentrations at around $8 \%$ of amino acids (NRC, 2011). The protein from seaweed flies are thus more similar to proteins of plant origin in this aspect. 
Table 4. Element composition of the seaweed media (the brown algae Laminaria digitata and Fucus serratus) and the two species of seaweed fly larvae (Coelopa frigida or Coelopa pilipes) grown on either $L$. digitata or $F$. serratus Data are expressed as mean values of three replicates \pm standard deviation for insects and the mean of two technical replicates for the seaweed media. ${ }^{1,2}$

$\begin{array}{lllll}\text { Seaweed media } & \text { C. frigida } & & \text { C. pilipes } \\ {\quad \text { F. serratus }} } & \text { L. digitata } \quad \text { F. serratus } & \text { L. digitata } \quad \text { F. serratus }\end{array}$

\begin{tabular}{|c|c|c|c|c|c|c|c|c|c|}
\hline \multicolumn{10}{|c|}{ (g/kg dw) } \\
\hline $\mathrm{Ca}$ & 3.2 & 4.3 & $28 \pm 4.1$ & $24 \pm 1.3$ & $46 \pm 5.3$ & $30 \pm 4.0$ & $* * *$ & ** & * \\
\hline $\mathrm{Na}$ & 1.7 & 6.0 & $11 \pm 0.8$ & $8.8 \pm 1.1$ & $16 \pm 6.1$ & $7.7 \pm 0.6$ & NS & * & NS \\
\hline K & 5.1 & 7.7 & $18 \pm 2.0$ & $18 \pm 2.4$ & $31 \pm 12$ & $15 \pm 1.4$ & NS & NS & NS \\
\hline $\mathrm{Mg}$ & 0.8 & 1.7 & $2.9 \pm 0.4$ & $4.3 \pm 1.0$ & $7.4 \pm 2.5$ & $7.0 \pm 1.3$ & ** & NS & NS \\
\hline P & 0.3 & 0.5 & $13 \pm 0.7$ & $15 \pm 3.8$ & $27 \pm 6.7$ & $20 \pm 2.7$ & ** & NS & NS \\
\hline \multicolumn{10}{|c|}{ (mg/kg dw) } \\
\hline $\mathrm{Mn}$ & 14 & 42 & $16 \pm 3.1$ & $116 \pm 51$ & $77 \pm 49$ & $118 \pm 9.6$ & NS & ** & NS \\
\hline $\mathrm{Fe}$ & 276 & 89 & $154 \pm 48$ & $86 \pm 9.2$ & $111 \pm 28$ & $70 \pm 19$ & NS & * & NS \\
\hline $\mathrm{Cu}$ & 3.8 & 0.8 & $11 \pm 1.7$ & $7.4 \pm 0.4$ & $8.1 \pm 0.5$ & $7.9 \pm 0.3$ & NS & ** & * \\
\hline $\mathrm{Zn}$ & 18 & 8.2 & $84 \pm 1.1$ & $95 \pm 7.5$ & $80 \pm 3.6$ & $83 \pm 3.1$ & * & * & NS \\
\hline Se & 0.08 & 0.03 & $0.10 \pm 0.01$ & $0.08 \pm 0.00$ & $0.09 \pm 0.00$ & $0.07 \pm 0.01$ & NS & * & NS \\
\hline As & 24 & 12 & $19 \pm 1.8$ & $11.3 \pm 0.6$ & $15.0 \pm 6.3$ & $11.3 \pm 4.5$ & NS & * & NS \\
\hline $\mathrm{Cd}$ & 0.11 & 0.31 & $1.5 \pm 0.8$ & $9.4 \pm 3.4$ & $6.8 \pm 5.3$ & $11.4 \pm 1.7$ & NS & * & NS \\
\hline $\mathrm{Hg}$ & 0.02 & 0.00 & $0.03 \pm 0.00$ & $0.01 \pm 0.00$ & $0.01 \pm 0.01$ & $0.01 \pm 0.00$ & ** & ** & NS \\
\hline $\mathrm{Pb}$ & 0.40 & 0.14 & $0.37 \pm 0.27$ & $0.27 \pm 0.11$ & $0.29 \pm 0.06$ & $0.21 \pm 0.03$ & NS & NS & NS \\
\hline
\end{tabular}

The remaining amino acid composition of the seaweed fly larvae was balanced and suitable for optimal nutrition of both animals and humans (NRC, 2011; WHO/FAO/UNU, 2007). Although there were some significant differences in amino acid composition due to insect species and seaweed feeding media in the current trial, the differences were only minor and not likely to give any difference in nutritional value of the protein fraction of the larvae.

Palmitoleic acid (16:1n-7), a minor fatty acid in plant sources, but present in fats of animal origin (Harwood et al., 1994; Orsavova et al., 2015), was high in all the seaweed fly larvae, irrespective of their growth media. Palmitoleic acid is a marker of endogenous lipid production (Paillard et al., 2008), as it is a product of the conversion of acetyl Co-A to fatty acids, here likely high in the larvae due to their accelerated growth and high rate of lipid deposition in the current developmental stage. The scientific community is not sure if the health effects of this fatty acid are purely positive or negative (De Fabiani, 2011), as it has been connected to both positive and negative health effects in dietary trials with rodents and human (Matthan et al., 2009; Nestel et al., 1994; Yang et al., 2011). Some 20:5n-3 (EPA) was also found in the larvae $(\sim 3.5 \%$ of total fatty acids), most likely just having been taken up from the algae and accumulated in the fat depositions. The concentration of EPA was much lower in the larvae than in the algae, so large parts of the EPA eaten by the larvae is probably oxidised and used as an energy source. No fatty acids longer than the 20-carbon EPA and none of the fatty acids being typical intermediates in the synthesis of PUFA were found, suggesting the larvae cannot perform the elongation steps necessary for these conversions. The sparse effects of the feeding media fatty acid composition on the fatty acid composition of the larvae also indicates that this insect species sent little dietary lipids directly to storage. Large parts of the fatty acids are therefore likely oxidised for energy and excess energy stored as their endogenously produced lipids, such as palmitoleic acid. This is in contrast with other insect species, such as black soldier fly, known to have a highly changed fatty acid composition when reared on different feeding media (Liland et al., 2017; St-Hilaire et al., 2007; Tschirner and Simon, 2015).

The concentrations of the macrominerals $\mathrm{Ca}, \mathrm{Na}$, and $\mathrm{P}$ were higher in $C$. pilipes than in $C$. frigida, suggesting that the uptake and use of these elements differ between the two insect species. The accumulated levels of Mn, Fe and $\mathrm{Cd}$ reflected the levels found in the seaweed feeding media: the higher the concentrations in the feeding media, the higher the concentrations in the larvae. This observation is in disagreement with findings for black soldier fly larvae; 
increased concentrations of Fe in feed media for black soldier fly larvae did not give any increase in larvae Fe concentrations (Liland et al., 2017). Both species of seaweed fly larvae accumulated $\mathrm{As}, \mathrm{Cd}$, and $\mathrm{Pb}$, but not $\mathrm{Hg}$ (the concentrations of $\mathrm{Hg}$ in the growth media were very low). This is partly in agreement with findings for black soldier fly larvae, which accumulated As and Cd, but not $\mathrm{Hg}$ and Pb (Biancarosa et al., 2017b; Diener et al., 2015; Purschke et al., 2017; Van der Fels-Klerx et al., 2016). Other minerals measured showed much less tendency to vary with the concentrations in the seaweed, suggesting the uptake of these might be regulated.

There is a great interest in the use of insect larvae as a feed ingredient in animal feed, including fish. In Europe, the level of undesirable substances are controlled through the feed legislation, which set maximum levels for a range of compounds, including arsenic and the heavy metals $\mathrm{Cd}, \mathrm{Hg}$, and $\mathrm{Pb}$, in feed ingredients and feed (Directive 2002/32/EC and amendments; EC, 2002). The levels of Hg and $\mathrm{Pb}$ in the seaweed fly larvae were low, and well below the current maximum levels set for feed ingredients $(0.1$ and $10 \mathrm{mg} / \mathrm{kg}$ feed ingredient, respectively, based on $12 \%$ moisture content; Figure 2). The levels of As and Cd in the seaweeds used in the growth media were below the current maximum levels, however the As and Cd levels in the fly larvae were above the current limits (Figure 2). The current maximum level for As in feed material are
$2 \mathrm{mg} \mathrm{As} / \mathrm{kg}$, with an exception for seaweed meal and feed material derived from seaweed for which the maximum level is $40 \mathrm{mg} / \mathrm{kg}$ (both based on $12 \%$ moisture content). The current maximum levels for $\mathrm{Cd}$ are $1 \mathrm{mg} / \mathrm{kg}$ in feed materials of vegetable origin and $2 \mathrm{mg} / \mathrm{kg}$ in feed materials of animal origin (based on $12 \%$ moisture content). The elevated levels of As and Cd in seaweed larvae (highest measured concentrations 18.4 and $11.6 \mathrm{mg} / \mathrm{kg}$, respectively) could potentially limit the use of seaweed fly larvae as a feed ingredient. The European Food Safety Authority has assessed the risks related to the production of insects for feed and food (EFSA, 2015). Several factors, such as growth substrate, insect species, growth stage of the insect and length of life cycle, will affect the accumulation and levels of undesirable substances in the insects. Of these, the growth substrate may have the largest affect, and occurrence of e.g. heavy metals and arsenic in insects can be controlled by managing the substrate, i.e. choosing a substrate with low levels of these elements.

In conclusion, seaweed flies could be a good source of nutrients for both human and animal nutrition, having a balanced composition of amino acids and being rich in unsaturated fatty acids. The high concentrations of As and $\mathrm{Cd}$ are, however, of concern and should be taken into account if production of these species should be upscaled for food or feed purposes.

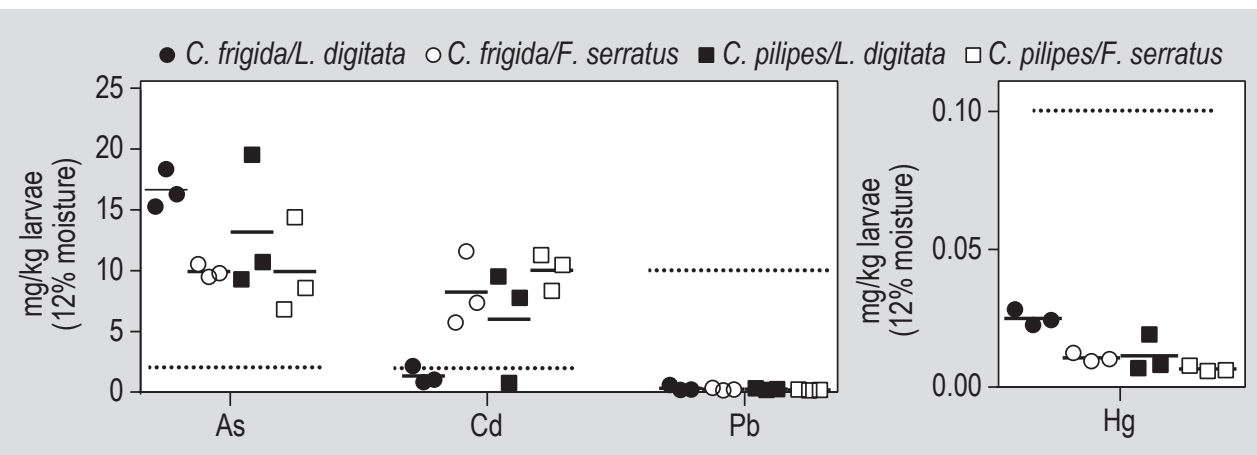

Figure 2. Composition of selected elements in two species of seaweed fly larvae (Coelopa frigida or Coelopa pilipes) grown on either Laminaria digitata or Fucus serratus. Data are expressed as the mean concentration of each mineral at $12 \%$ moisture level to be compared to EU's official maximum levels for each element in animal feed (Directive 2002/32/EC and amendments; EC, 2002). All three data points per group are plotted together with the mean value of each group plotted as a solid line. The stapled lines indicate the maximum permitted level in feed material for each element set by the EU.

\section{References}

Ackman, R.G., 1980. Fish lipids. In: Connell, J.J. (ed.) Advances in fish science and technology. Papers presented at the Jubilee Conference of the Torry Research Station, Aberdeen, Scotland, July 23-27, 1979. Fishing News Books, Farnham, UK, pp. 87-103.
Barroso, F.G., De Haro, C., Sanchez-Muros, M.J., Venegas, E., MartinezSanchez, A. and Perez-Banon, C., 2014. The potential of various insect species for use as food for fish. Aquaculture 422: 193-201.

Biancarosa, I., Espe, M., Bruckner, C., Heesch, S., Liland, N., Waagbø, R., Torstensen, B. and Lock, E., 2017a. Amino acid composition, protein content, and nitrogen-to-protein conversion factors of 21 seaweed species from Norwegian waters. Journal of Applied Phycology 29: 1001-1009. 
Biancarosa, I., Liland, N.S., Biemans, D., Araujo, P., Bruckner, C.G., Waagbo, R., Torstensen, B.E., Lock, E.J. and Amlund, H., 2017b. Uptake of heavy metals and arsenic in black soldier fly (Hermetia illucens) larvae grown on seaweed-enriched media. Journal of the Science of Food and Agriculture 98: 2176-2183.

Cullen, S.J., Young, A.M. and Day, T.H., 1987. Dietary requirements of seaweed flies (Coelopa frigida). Estuarine, Coastal and Shelf Science 24: 701-710.

De Fabiani, E., 2011. The true story of palmitoleic acid: between myth and reality. European Journal of Lipid Science and Technology 113: 809-811.

Diener, S., Zurbrügg, C. and Tockner, K., 2015. Bioaccumulation of heavy metals in the black soldier fly, Hermetia illucens and effects on its life cycle. Journal of Insects as Food and Feed 1: 261-270.

Dobson, T., 1974. Studies on the biology of the kelp-fly Coelopa in Great Britain. Journal of Natural History 8: 155-177.

Dunn, D.W. and Crean, C.S., 2002. The effects of exposure to seaweed on willingness to mate, oviposition, and longevity in seaweed flies. Ecological Entomology 27: 554-564.

Edward, D.A., Blyth, J.E., McKee, R. and Gilburn, A.S., 2007. Change in the distribution of a member of the strand line community: the seaweed fly (Diptera: Coelopidae). Ecological Entomology 32: 741-746.

European Commission (EC), 2002. Directive 2002/32/EC of the European Parliament and of the Council of 7 May 2002 on undesirable substances in animal feed. Available at: http://data. europa.eu/eli/dir/2002/32/2015-02-27.

European Food Safety Authority (EFSA), 2015. Risk profile related to production and consumption of insects as food and feed. EFSA Journal 13: 4257-4317.

Fontaneto, D., Tommaseo-Ponzetta, M., Galli, C., Risé, P., Glew, R.H. and Paoletti, M.G., 2011. Differences in fatty acid composition between aquatic and terrestrial insects used as food in human nutrition. Ecology of Food and Nutrition 50: 351-367.

Harwood, J.L., Padley, F.B. and Gunstone, F.D., 1994. Ocurrence and characteristics of oils and fats. The lipid handbook. Chapman \& Hall, London, UK, 722 pp.

Henry, M., Gasco, L., Piccolo, G. and Fountoulaki, E., 2015. Review on the use of insects in the diet of farmed fish: past and future. Animal Feed Science and Technology 203: 1-22.

Julshamn, K., Dahl, L. and Eckhoff, K., 2001. Determination of iodine in seafood by inductively coupled plasma/mass spectrometry. Journal of AOAC International 84: 1976-1983.

Liland, N.S., Biancarosa, I., Araujo, P., Biemans, D., Bruckner, C.G., Waagbø, R., Torstensen, B.E. and Lock, E.-J., 2017. Modulation of nutrient composition of black soldier fly (Hermetia illucens) larvae by feeding seaweed-enriched media. PLoS ONE 12: e0183188.

Makkar, H.P.S., Tran, G., Heuzé, V. and Ankers, P., 2014. State-ofthe-art on use of insects as animal feed. Animal Feed Science and Technology 197: 1-33.

Matthan, N.R., Dillard, A., Lecker, J.L., Ip, B. and Lichtenstein, A.H., 2009. Effects of dietary palmitoleic acid on plasma lipoprotein profile and aortic cholesterol accumulation are similar to those of other unsaturated fatty acids in the F1B golden Syrian hamster. Journal of Nutrition 139: 215-221.
Nestel, P., Clifton, P. and Noakes, M., 1994. Effects of increasing dietary palmitoleic acid compared with palmitic and oleic acids on plasma lipids of hypercholesterolemic men. Journal of Lipid Research 35: 656-662.

National Research Council (NRC), 2011. Nutrient requirements of fish and shrimp. National Academies Press, Washington, DC, USA, $363 \mathrm{pp}$.

Orsavova, J., Misurcova, L., Vavra Ambrozova, J., Vicha, R. and Mlcek, J., 2015. Fatty acids composition of vegetable oils and its contribution to dietary energy intake and dependence of cardiovascular mortality on dietary intake of fatty acids. International Journal of Molecular Sciences 16: 12871-12890.

Paillard, F., Catheline, D., Duff, F.L., Bouriel, M., Deugnier, Y., Pouchard, M., Daubert, J.-C. and Legrand, P., 2008. Plasma palmitoleic acid, a product of stearoyl-coA desaturase activity, is an independent marker of triglyceridemia and abdominal adiposity. Nutrition, Metabolism and Cardiovascular Diseases 18: 436-440.

Purschke, B., Scheibelberger, R., Axmann, S., Adler, A. and Jager, H., 2017. Impact of substrate contamination with mycotoxins, heavy metals and pesticides on the growth performance and composition of black soldier fly larvae (Hermetia illucens) for use in the feed and food value chain. Food Additives and Contamintants, part A 34: 1410-1420.

R Development Core Team, 2017. R: a language and environment for statistical computing. R Foundation for Statistical Computing, Vienna, Austria.

St-Hilaire, S., Cranfill, K., McGuire, M.A., Mosley, E.E., Tomberlin, J.K., Newton, L., Sealey, W., Sheppard, C. and Irving, S., 2007. Fish offal recycling by the black soldier fly produces a foodstuff high in omega-3 fatty acids. Journal of the World Aquaculture Society 38: 309-313.

Torstensen, B.E., Frøyland, L. and Lie, Ø., 2004. Replacing dietary fish oil with increasing levels of rapeseed oil and olive oil - effects on Atlantic salmon (Salmo salar L.) tissue and lipoprotein lipid composition and lipogenic enzyme activities. Aquaculture Nutrition 10: 175-192.

Tschirner, M. and Simon, A., 2015. Influence of different growing substrates and processing on the nutrient composition of black soldier fly larvae destined for animal feed. Journal of Insects as Food and Feed 1: 249-259.

Van der Fels-Klerx, H.J., Camenzuli, L., Van der Lee, M.K. and Oonincx, D.G., 2016. Uptake of cadmium, lead and arsenic by Tenebrio molitor and Hermetia illucens from contaminated substrates. PLoS ONE 11: e0166186.

Veldkamp, T., Van Duinkerken, G., Van Huis, A., Lakemond, C.M.M., Ottevanger, E., Bosch, G., Van Boekel, M.A.J.S., 2012. Insects as a sustainable feed ingredient in pig and poultry diets - a feasibility study. Wageningen Livestock Research, Wageningen, the Netherlands, 62 pp.

World Health Organization/Food and Agriculture Organization of the United Nations/United Nations University (WHO/FAO/UNU), 2007. Protein and amino acid requirements in human nutrition. Report of a joint FAO/WHO/UNU expert consultation. WHO Technical Report Series 935, WHO, Geneva, Switzerland, 265 pp.

Yang, Z.-H., Miyahara, H. and Hatanaka, A., 2011. Chronic administration of palmitoleic acid reduces insulin resistance and hepatic lipid accumulation in KK-Ay Mice with genetic type 2 diabetes. Lipids in Health and Disease 10: 120. 